\title{
Unraveling groundwater contributions to evapotranspiration in a mountain headwaters: Using eddy covariance to constrain water and energy fluxes in the East River Watershed
}

\author{
Anna Elizabeth Chovanes Ryken ${ }^{1}$, David Gochis ${ }^{2}$, and Reed Maxwell ${ }^{1}$ \\ ${ }^{1}$ Colorado School of Mines \\ ${ }^{2} \mathrm{NCAR}$
}

July 24, 2020

\begin{abstract}
Despite the importance of headwater basins for western United States' water supply, these regions are often poorly understood, particularly with respect to quantitative understanding of evapotranspiration (ET) fluxes. Heterogeneity of land cover, topography, and atmospheric patterns in these high-elevation regions lead to difficulty in developing spatially distributed characterization of ET. As a significant fraction of the water budget, ET contributes to overall water and energy availability in the basin. Using an eddy covariance tower in the East River Basin, a Colorado River headwaters basin, this study improves the quantification of water and energy fluxes in high-elevation, complex systems to better constrain ET estimates and calculate overall water and energy budgets. The eddy covariance method estimates ET from years 2017 through 2019 at a saturated, riparian end-member site. During the late spring, summer, and early fall months, due to strong variations in lower atmospheric stability and evidenced by a less than $30 \%$ energy balance closure error in these months (within the range of closure error reported at other riparian locations) we conclude that the eddy covariance method is useful in high-elevation, complex areas such as the East River Basin and helps bound regional ET estimates. We also compared East River ET magnitudes and seasonality to two other eddy covariance towers (Niwot Ridge, CO and Valles Caldera, NM), with similar site characteristics, located in the Rocky Mountains. East River ET estimations are useful for constraining water budget estimates at this energy-limited site, which uses groundwater for up to $76 \%$ of ET in the summer months. This data is useful for constraining ET estimates in similar end-member locations; however, to better constrain ET estimates across the entire East River basin, additional sampling is needed. This study helps constrain both the energy and water budgets in locations that are underrepresented by observations and where indirect estimates of ET may perform poorly.
\end{abstract}

\section{Key Words}

Evapotranspiration, Eddy Covariance, Energy, Water, Fluxes, Headwaters

\section{Background}

Mountain headwater regions provide much of the world's water (Chang, Foster, Hall, Rango, \& Hartline, 1982; Ikeda et al., 2010) and in the western United States, the Colorado River provides water for 30 million people and 4 million acres of irrigated agriculture (Reclamation, 2012). However, many western watersheds lose more water to the atmosphere through evaporation and transpiration (ET) than is discharged into rivers and streams (Knight, Fahey, \& Running, 1981; Trenberth, Smith, Qian, Dai, \& Fasullo, 2007). In the Western U.S., ET is often the second largest component of the water balance, after precipitation, and is also associated with a watershed's energy balance making accurate estimations of this flux vitally important to overall water availability predictions (Healy, Winter, LaBaugh, \& Franke, 2007) as well as regional energy budgets. A recent study by Milly and Dunne (2020) estimates that the mean annual discharge of the Colorado 
River is decreasing due to increased evapotranspiration while another study shows similar trends in the Alps with an air temperature increase causing an increase in ET leading to a decrease in runoff consistent with a $3 \%$ precipitation decrease (Mastrotheodoros et al., 2020). Both studies reveal the importance of ET flux to overall water availability. However, ET is challenging to quantify in headwaters regions as these regions are often marked by complexities such as heterogeneous land cover, large topographic gradients, and spatially varying atmospheric patterns. Due to these complexities, few studies have tested the effectiveness of measuring ET in complex headwaters regions (Flerchinger, Marks, Reba, Yu, \& Seyfried, 2010).

Eddy covariance is a commonly used technique for quantifying latent heat - equivalent to ET multiplied by the latent heat of vaporization of water at a given temperature - and often used interchangeably with ET in this paper (Ceperley et al., 2017; Hirschi, Michel, Lehner, \& Seneviratne 2017; Maes, Gentine, Verhoest, \& Miralles, 2019; Mamadou et al., 2014). This method computes the flux as the covariance between deviation from the mean of the vertical wind speed and deviation from the mean of the concentration multiplied by the air density (Burba, 2013). This method is effective in flat terrain with homogenous land cover due to the assumptions that must be made using this technique, including the lack of surface heterogeneity, adequate fetch, and turbulent fluxes (Burba \& Anderson, 2006). This then leads to difficulty in predicting how these water and energy fluxes, and overall water availability, will change with a changing climate.

Despite the challenges outlined above, some studies have successfully used the eddy covariance in highelevation environments. Burns, Blanken, Turnipseed, Hu, \& Monson (2015) studied how changes in precipitation affect the overall surface energy budget in a high-elevation forest while Frank, Massman, Ewers, Huckaby, \& Negrón (2014) studied how disturbances, such as bark beetles, shift the energy balance components in the Rocky Mountains. Complimentary studies have also used eddy covariance in western riparian areas leading to helpful end-member ET values, which range from 10 to $30 \%$ surface energy balance closure error (Nagler et al., 2005; Scott et al., 2004; Scott et al., 2008; Wilson et al., 2002). Through the measurement of these fluxes and thus better estimations of the water and energy balances, these studies allow for a better understanding of energy fluxes in mountain environments and result in data sets that can be used to check model performance.

In this study, we improve the quantification of water and energy fluxes in high-elevation, complex systems, we estimate groundwater contributions to ET, and we compare our results to other sites in the Rocky Mountain region. Our study site, a basin that contributes to the Upper Colorado River Basin and eventually the Colorado River, provides an archetype of other Rocky Mountain basins. Our study period includes multiple water years characterized by both wet and dry conditions resulting in ET estimations useful for application across the entire basin and to other headwaters regions. This study leads to greater understanding of water availability in headwaters systems, which can then be used for ecological and hydrological applications and downstream water planning.

\section{Methods}

\subsection{East River Region}

In our study, we installed an eddy covariance tower in the approximately $85 \mathrm{~km}^{2}$ East River watershed near Crested Butte, Colorado (38.922242, -106.949699). The East River is part of the headwaters of the Upper Gunnison River, which is a primary tributary to the Colorado River, provides much of the flow to the Upper Colorado River Basin, and is a site typical of high-elevation watersheds with minimal human disturbance. Due to the basin's influence on water availability in the west, it is a U.S. Department of Energy Scientific Focus Area (DOE-SFA) where many researchers are studying earth systems processes from the bedrock to lower atmosphere to better understand the hydrologic behavior mountain watersheds (Hubbard et al., 2018). It is a semi-arid, snowmelt-dominated watershed where much of the downstream water comes from the snow stored in these mountains during the winter. The basin's land cover is highly heterogeneous with about $38 \%$ classified as shrub/scrub, $23 \%$ as evergreen forest, $13 \%$ as barren land, $11 \%$ as deciduous forest, $7 \%$ as grassland, and the remainder split between 10 other land cover types classified by the NLCD 2011 (Yang et al., 2018) (Figure 1). The tower sits in a valley at an elevation of about $2800 \mathrm{~m}$ with mountain peaks on 
either side that reach about $3700 \mathrm{~m}$ in elevation. The East River runs through the valley next to the tower and the site is covered in snow for six months of the year and, if it is a wet year, the ground is saturated for about one to two months in early summer.

Due to the complexities of eddy covariance inherent in mountain regions, we located the tower to minimize terrain influences, provide a consistent fetch, and capture the upper-bound floodplain ET behavior (Figure $1 \mathrm{~b}, \mathrm{c}, \mathrm{d})$. The tower was oriented so that the tower would mainly capture turbulence coming from the dominant, northwestern (up-valley), wind direction (Figure 2). The valley also gives saturated, end-member observations as evidenced by the soil moisture data throughout the study period, which shows the subsurface is saturated, has standing water or is near saturation for large fractions of the year (Figure 3). Observations at this endmember site allow us to constrain the upper values of latent heat flux in the basin given that this area is going to be the area with the greatest potential ET.

\subsection{Eddy Covariance Tower Instrument Details}

The eddy flux tower shown in Figure 1 stands at six meters high and supports multiple sensors. The sensor suite for the eddy covariance (EC)/energy balance system are provided in Table 1 and include air temperature and humidity sensors, a snow depth sensor, an air pressure transducer, a three-dimensional sonic anemometer with integrated $\mathrm{CO}_{2}$ and $\mathrm{H}_{2} \mathrm{O}$ open-path gas analyzer, two levels of soil moisture, soil temperature and soil electrical conductivity $(5 \mathrm{~cm}$ and $25 \mathrm{~cm}$ ), and ground heat flux plates located at a $5 \mathrm{~cm}$ depth. The measurement height for the eddy covariance/infra-red gas analyzer and 4-way radiometer was set at just below $6 \mathrm{~m}(5.9 \mathrm{~m})$ which is approximately 3-4 meters above the willow shrub gallery that covers much of the valley floor. The data recorded by these sensors are then processed using the EasyFlux-DL software following AmeriFlux guidelines (Aubinet, Vesala, \& Papale, 2012, see Table 2 for description of EC processing options). Final data is output in 30-minute time increments. Data was then checked for reasonableness and missing time stamps are added, but no data was averaged to fill in the missing time gaps. This allows for the closest representation of tower measurements at the site. In this study, we have analyzed the data from April 15, 2017 to September 27, 2019. Energy balance closure was also assessed as a means of filtering out periods of incorrect or otherwise unreliable data. Details on closure analysis are provided below in Sections 2.3 and 3.1.

\subsection{Water and Energy Budget Partitioning}

The amount of energy going into the system should be offset by the amount of energy used by the system; therefore, the net radiation into the system should be accounted for by the total heat fluxes of the system:

$R n-G=L E+H+i$ Eq. 1

where $R n$ is the net radiation, $L E$ is the latent heat, $H$ is the sensible heat, and $i$ is the source/sink term with all components in $\mathrm{W} / \mathrm{m}^{2}$. We conducted an energy balance closure on all three water years. We considered errors less than $30 \%$ to represent good closure; that our observations resulted in a $30 \%$ closure error or less, meaning at least $70 \%$ of the net radiation is accounted for by ground, sensible, and latent fluxes. Given that we are not measuring the thermal energy in the snowpack, of the water that pools on the surface just after snowmelt, of the vegetation canopy or canopy airspace or other energy exchange processes along with the atmospheric complexities of mountain environments (Finnigan, 2004), 30\% is a realistic closure estimate. This closure percentage is consistent with previous riparian and mountain area studies that resulted in closure errors of 10 to 30 percent (Eshonkulov et al., 2019; Nagler et al., 2005; Scott et al., 2004; Scott et al., 2008; Wilson et al., 2002).

\section{Results and Discussion}

\subsection{Energy Balance Closure}

The eddy covariance data is averaged to daily time steps then the closure error percentage is calculated per day as:

$\%$ closure error $=\frac{(R n-G)-(L E+H)}{\mathrm{Rn}} * 100 \mathrm{Eq} .2$ 
This daily closure error was then averaged to monthly closure error (Figure 4) for seasonal analysis. The closure error is generally smaller in spring and summer months than in winter months. Months with negative closure mean the combined latent, ground, and sensible heat fluxes are greater than the radiation possibly resulting from the saturated nature of the area resulting in large latent heat fluxes despite lower radiation. The month with the least closure error is March 2018 followed by August 2017, with closures of $0.163 \%$ and $3.39 \%$, respectively. In March 2018, net radiation is low, but also, the heat fluxes are small contributing to a small closure percentage. The winter of 2018 was also a dry year with minimal snow, which could also contribute to this smaller closure error. When the ground is saturated it is possible that some of the energy penetrating the ground surface is used to heat water that runs off into the stream leaving some energy fluxes unaccounted for by the tower. Once the ground is no longer saturated and the snowpack is gone, incoming energy can contribute more directly to the heat flux terms in Eq. 2.

These results also show that summer closure is better, on average, than fall and winter closure. In winter, the site is covered in snow and a comparatively stable planetary boundary layer (PBL) persists, which creates smaller eddies and laminar flow which makes it difficult for the sensor to measure heat fluxes (Baldocchi, Hinks, \& Meyers, 1988; Eshonkulov et al., 2019). A more stable PBL and more laminar flow regime may also be resulting in a much greater flux measurement sampling area or "footprint" which may come from hillslope or other non-riparian areas. Prevailing winds are also much stronger during the winter time, particularly during storm events, which may also contribute to enlargement of the flux tower footprint. Lastly, we are not explicitly accounting for the thermal energy stored in the snowpack, nor within standing water under the tower, which would be absorbing (or releasing) energy and is therefore unaccounted for by the tower measurements. Combined, the closure error results show that the energy flux estimates are less reliable in the winter as the closure error is much larger and all of the energy in the system is not accounted for by the heat fluxes or there is more energy in the form of heat fluxes than is accounted for by incoming net radiation. Therefore, from here on, our analyses focus predominantly on the warm season flux characteristics.

To better understand the daily cycle of energy components during the time of good energy balance closure, we averaged the net radiation, latent heat, sensible heat, ground heat, and closure error percentage at each hour of the day from June 1 to August 31 for all years. Solar noon is also shown (Figure 5). Net radiation is greatest at 14:00 MT (local time) with sensible heat reaching its maximum at the same time. Latent heat reaches its maximum slightly later due to the delay in energy transfer as this system seems to be more energy-limited. Ground heat takes the longest to reach its peak as the heat transfer from the atmosphere to the subsurface takes the most time. The diurnal data also shows the decrease of closure error throughout the day with the best closure occurring at 18:00 around the same time as the ground heat flux maximum. Closure error is larger in the evening and early morning when the atmosphere tends to be more stable and eddies are smaller resulting in more difficult measurements of sensible and latent heat fluxes. The eddy covariance tower behavior is reasonable for this riparian area, thus giving us confidence in the flux tower data.

\subsection{Summer Energy and Water Flux Comparisons}

Most of the annual ET occurs over the summer months (Table 3), and closer errors are lowest during these times, so we then compared datasets of summers (June-August) 2017, 2018, and 2019. We averaged latent heat, total net radiation $(\mathrm{Rn}-\mathrm{G})$, air temperature, and dewpoint depression for each summer using the same dates for all variables across each summer. We calculated ET (latent heat flux multiplied by the latent heat of vaporization) for all three summers along with the total ET for the water year (water year 2017 is shortened and begins when we installed the tower in April 2017). This table includes the total precipitation for each water year, which was obtained from a precipitation gage located within the East River basin at an elevation approximately $200 \mathrm{~m}$ higher and $6.2 \mathrm{~km}$ northwest of the flux tower (Billy Barr station). Average latent heat flux is greatest during the summer 2018 with summer 2019 having the lowest average latent heat flux (Table 3). The table shows that the differences between summers of available energy, ET, latent heat, and air temperature are much less across the three summers than the differences in precipitation. 2019 had the greatest precipitation with the year of lowest precipitation, 2018, being 400mm less. Total summer ET does not follow the same patterns with the largest ET value occurring during the lowest precipitation 
year. Similar to the findings of Scott et al. (2008), ET is not as variable as precipitation over the three study years. While precipitation varies by $30 \%$ across the three years, ET varies by only $14 \%$ suggesting that precipitation is not the primary driver (or limiter) of ET in this system and confirming that this site is generally a saturated end-member site, which is not water-limited for ET.

We then compared these summers on a time series (Figure 6). All three summers have similar monthly patterns and magnitudes of ET showing overall site consistency across three water years despite large differences in precipitation (Figure 6b). However, ET is at times inversely correlated to soil moisture at both $5 \mathrm{~cm}$ and $25 \mathrm{~cm}$ (Figure $6 \mathrm{c}, \mathrm{d}$ ). For example, figure $6 \mathrm{~d}$ shows soil moisture at $5 \mathrm{~cm}$ and we see that May and June respond to snowmelt with the highest average soil moisture in 2019. However, ET for May and June of 2019 is the lowest of the three summers. Available energy also does not correlate perfectly with the patterns seen in ET across the three years (Figure 6a). The years with greatest average monthly available energy do not always result in years with the greatest average monthly ET. This data, along with the data shown in table 3, seems to suggest that ET and soil moisture are, at times, inversely correlated indicating that water for ET comes not just from shallow soil moisture, but also from other sources such as deeper groundwater or ponded water.

The drying of soil moisture throughout the summer can also be observed in the May through September groundwater use values (Table 4). This is a critical time for vegetation as the spring snowmelt recharges soil moisture and groundwater and this plant water source is drained by vegetation until the availability of summer rainfall. There is substantial evidence that plants also access groundwater, particularly during this time in mountain systems (Bearup, Maxwell, Clow, \& McCray, 2014). Using an equation from Scott et al. (2008) (Equation 3), we can estimate how much ET comes from groundwater over the summer for years 2017, 2018, and 2019 as follows:

$\mathrm{ET}_{\mathrm{gw}}=E T-(P-S)$, Eq. 3

where $E T_{g w}$ is ET from groundwater, ET is total evapotranspiration, $P$ is precipitation, and [?]S is the change in soil moisture in the top $30 \mathrm{~cm}$ of soil from May to September. Runoff is assumed to be negligible since we are calculating $\mathrm{ET}_{\mathrm{gw}}$ over the area of the eddy flux tower footprint. Positive $\mathrm{ET}_{\mathrm{gw}}$ indicates $\mathrm{ET}$ is greater than precipitation and soil moisture change resulting in ET drawing from older groundwater. The $\mathrm{ET}_{\mathrm{gw}}$ values for all three summers are positive indicating that groundwater supplies a fraction of ET regardless of precipitation. ET drew most heavily from groundwater in the summer of 2017 (76.2\%) closely followed by 2019 (75.5\%), with the summer of 2018 having the least amount of groundwater use. While 2018 had the least precipitation annually (Table 3), much of the annual precipitation occurred during the summer months leading to less groundwater use than the other two summers showing a reliance on rainwater for summer 2018 rather than a reliance on groundwater due to snowmelt. These summers offer insight into the variability of ET groundwater use across water years. Though the magnitude of precipitation is crucial for ET, the timing of precipitation across the year dictates whether ET needs to draw from groundwater as in 2017 and 2019 when ET seems to use water from snowmelt, or whether ET coincides with summer rain as in the case of 2018. This shift in water sources is suggested by simulations (Bearup et al., 2014; Kollet \& Maxwell, 2008; Maxwell \& Condon, 2016; Maxwell, Condon, Danesh-Yazdi, \& Bearup, 2019) and corroborated by shallow groundwater observations on a hill slope adjacent to the tower site that confirm that vegetation would have access to groundwater along riparian flood plain (Tokunaga et al., 2019).

Without access to groundwater, ET values would decrease substantially in 2017 and 2019 as the only contributing water, we estimate, would be from precipitation and soil moisture resulting in $71.82 \mathrm{~mm}$ and $65.21 \mathrm{~mm}$ of ET for summers of 2017 and 2019, respectively. These ET values are what we might expect as a low end-member at higher elevations on ridge tops where land-surface energy processes may be disconnected from groundwater (Kollet \& Maxwell, 2008; Maxwell \& Kollet, 2008), and may not have as much access to groundwater as the flux tower location, which sits in a convergent zone. While subject to uncertainty, these estimates indicate that groundwater may increase ET values by up to $76 \%$ making it critical to better constrain these higher elevation water fluxes. As soil structure and soil moisture conditions vary across the East River basin it is important to provide additional observations of ET to constrain this variability. 


\subsection{Comparisons to East River Basin and Rocky Mountain Headwaters}

To estimate the amount of water leaving the system through latent heat flux, we calculated evapotranspiration using the latent heat from the tower and the latent heat of vaporization. We compared our eddy flux estimates with those from another flux tower in the central Rocky Mountain region, operational since 1998, located at the Niwot Ridge Ameriflux site (US-NR1) in Colorado about 174km northeast of the East River Basin (Burns et al., 2015; Monson et al., 2002) (Figure 7). The daily ET values at the East River site compare well with those at Niwot Ridge with both locations having obvious seasonal cycles with ET increasing as the snow melts in the spring, reaching a peak in summer, and decreasing as both water and energy availability decrease in the fall and winter. ET is greatest during the summer of 2018, followed by summer 2017, then 2019 in the East River location. Both locations are high-mountain environments, though the East River has more heterogeneous land cover, as Niwot Ridge is characterized by an evergreen needleleaf forest, and the East River has greater water availability throughout the year as the flux tower sits in a saturated valley $300 \mathrm{~m}$ lower than the Niwot Ridge tower.

We also compared the East River data to the Valles Caldera AmeriFlux tower (US-Vcp) (Table 5) located in southern Rocky Mountain region in north-central New Mexico in the Jemez River Basin. This site is characterized by Ponderosa Pine and Gambel Oak and sits below the flux tower at an elevation of $2500 \mathrm{~m}$ (Litvak, 2007). Comparison of the East River, Valles Caldera, and Niwot Ridge flux towers allows for scaling estimates of ET across the rest of the East River basin as these three locations represent locations typical of Rocky Mountain headwaters catchments as well as a variety of elevations and land covers similar to those found at various locations inside the East River basin, which is mostly characterized by shrub/scrub, evergreen forest, barren land, and deciduous forest.

The Valles Caldera has the greatest ET both annually and seasonally across all three years of study. Valles Caldera receives the least amount of cumulative precipitation across the three years, but this location has the greatest energy input shown in the largest temperatures leading to larger ET values. East River ET is the next largest for summer (June-August) ET in all years except 2017 where Niwot Ridge is slightly larger; however, Niwot Ridge annual ET is greater than East River ET in 2018 and 2019 while East River annual ET is greater in 2017. Niwot Ridge had the greatest annual ET in 2019 while the summer ET was greatest in 2017. In 2019, Niwot Ridge had lower overall summer values, but they remained consistent from April to September making 2019 the year with the largest annual ET at Niwot Ridge, whereas 2017 experienced larger summer values with lower values in the surrounding months making 2017 the year with the largest summer ET. Both the East River and Valles Caldera experienced the greatest annual and summer ET during the same years (2018 and 2019, respectively).

The maximum summer ET values seem to correspond to the years with greatest precipitation at the two sites outside of the East River. Both Valles Caldera and Niwot Ridge seem to be moisture limited sites with the amount of precipitation and available water dictating the maximum ET in the dry summer months, whereas the East River site is more dependent on energy as it is located in a saturated end-member location and variations in precipitation have less effect on ET than variations in energy.

\section{Discussion}

To better understand the variability in precipitation and ET across the basin over the three water years, we calculated the water balance at the East River valley location using the equation,

residual $=P-\mathrm{ET}-Q-S$, Eq. 4

where $E T$ is total evapotranspiration, $P$ is precipitation, $Q$ is the runoff at the outlet of the East River basin co-located with the flux tower (Carroll \& Williams, 2019), and [?]S is the change in soil moisture in the top $30 \mathrm{~cm}$ of soil (Table 6). For water year 2017, ET is only available for April 15 through September 30. For the remaining water years, ET is available for the full water year with some interspersed data gaps. Using the daily ET values, we also gap-filled the ET data by taking the linear average ET of the days surrounding the missing data to get an understanding of the range in ET at the end-member site. $Q$ is calculated for the 
full water years based on a basin area of $85 \mathrm{~km}^{2} . P$ represents the three full water years and we used values from both the Billy Barr meteorological station as well as from the Schofield SNOTEL station located at the northern edge of the watershed at approximately $3260 \mathrm{~m}$ in elevation and $13.4 \mathrm{~km}$ northwest of the flux tower and discharge outlet (Natural Resources Conservation Service). We also calculated an effective precipitation at each station to account for sublimation from the canopy, surface, and blowing snow, which is not captured by the flux tower. We left the summer precipitation unchanged and removed $28 \%$ of precipitation in the winter based on the percentages of winter sublimation values in open, forested, and alpine sites by Sextone et al. (2018). [?]S is equal to the values found in Section 3.2 (Table 4).

While the flux tower is useful in estimating ET in complex, headwaters regions, it is an uncertain variable in the water balance. When ET is gap-filled, we see an increase in ET of $17 \%, 22 \%$, and $13 \%$ for water years 2017, 2018, and 2019, respectively. This increase in ET has significant impacts on the residual of the water balance, increasing the residual when the system is losing water and decreasing the residual when the system is gaining.

This variability can also be seen in the precipitation. In 2017, the Billy Barr station records precipitation that is approximately half of what is registered at the Schofield station while 2019 has a difference of $555 \mathrm{~mm}$ of precipitation. This variability could have large consequences as it alters the amount of water available in the system depending on the station used for water balance calculations (Table 7).

This variability in precipitation and ET is evident in the residuals of the calculated water balance for the basin (Table 7). When using Billy Barr precipitation in 2017, the system is losing water. However, when we use Schofield precipitation that same year, the system is gaining water for both the original and gap-filled ET values. Though water years 2018 and 2019 are both losing water, the difference in the amount of water lost is large between using Billy Barr precipitation and Schofield precipitation regardless of ET estimations. The difference in residuals when using the original ET as opposed to the gap-filled ET is $66.13 \mathrm{~mm}, 98.48 \mathrm{~mm}$, and $54.79 \mathrm{~mm}$ for water years 2017, 2018, and 2019, respectively at both Billy Barr and Schofield. This increase in ET using the gap-filled values leads to greater water usage and a decline in the residual resulting in less water available per year.

The variability in residuals due to variability in precipitation and ET has large implications for water balance estimations and water use in the East River basin. If the water balance shifts by $55 \mathrm{~mm}$ to $100 \mathrm{~mm}$ per year based on ET estimations, these estimations become vitally important for water availability estimations. We also only have ET estimations at one location in the basin, which is not very near either of the precipitation gages. The precipitation data is equally important as it can swing the basin from a gaining system when using one set of data to a losing system when using data from another location as seen in the residuals from 2017, which was considered a wet year for this basin. This variability makes the water balance difficult to estimate across the entire East River basin without access to more data highlighting the need for meteorological stations for precipitation and eddy covariance towers for ET estimations to constrain the variability in these fluxes.

\section{Future Study}

Given the existence of only flux tower in the East River basin, more towers and data are needed to draw firm conclusions about ET values across the rest of the basin. The data from both the Niwot Ridge and Valles Caldera flux towers give us some insight into estimates of ET at other locations throughout the East River. The East River ET values likely represent the lower-bound estimates of ET given missing data (especially during the months of August and September) at various times in water years 2017, 2018, and 2019. We would expect the ET values at the East River to increase at both the seasonal and annual time scales probably surpassing ET values at Niwot Ridge, as seen in Section 4 when ET is gap-filled. The Niwot Ridge site is useful in helping to quantify ET at higher elevations in the east River basin during the summer months. These high-elevation locations are often marked by evergreen needleleaf land cover, greater wind speeds, lower temperatures, and lower soil moisture. We hypothesize that ET is lower at higher elevations in the East River basin - more closely resembling values from Niwot Ridge - than the riparian area where the flux 
tower currently sits. While we would expect ET to be similar to the Valles Caldera values at lower elevations with greater radiation; the location of the East River eddy flux tower sits at one of the most saturated and lowest elevations locations within the East River basin. Therefore, we expect the rest of the basin ET to be less than or equal to the measured East River ET flux values.

This site comparison helps constrain ET not only across the East River basin leading to a better understanding of water availability, but also across the rest of the Rocky Mountains. The East River flux tower offers useful information at a highly heterogeneous, yet vital, headwaters region about energy and water fluxes that differs from the only two currently operational AmeriFlux and/or FLUXNET sites in the Rocky Mountains, Valles Caldera and Niwot Ridge. By adding the flux tower at the East River site, we increase the number of eddy covariance towers in the Rocky Mountains by $50 \%$. Understanding the high, endmember ET values allow for estimations to be made across the rest of the basin and Rocky Mountains leading to better understanding of water availability in historically underrepresented, complex locations. These flux tower comparisons also highlight the need for more flux towers in these heterogeneous mountain environments. End-member analysis is useful for constraining the higher end of ET in the East River basin; however, a larger number of flux towers at diverse locations across the basin - and the rest of the Rocky Mountains - would ensure better water and energy availability estimations useful for downstream planning.

\section{Conclusions}

This study shows the eddy covariance method can be used in a saturated end-member, complex, mountain region. This method led to less than $30 \%$ closure error in the spring and summer months showing that most of the energy coming into the system can be quantified and partitioned between latent, ground, and sensible heat fluxes. This closure error is within the ranges found at other study sites in mountain regions and riparian areas of 10 to 30\% closure error (Eshonkulov et al., 2019; Nagler et al., 2005; Scott et al., 2004; Scott et al., 2008; Wilson et al., 2002) and the daily ET values for the range of the study period are similar to those found at the Niwot Ridge AmeriFlux site (about 0 to $5 \mathrm{~mm} /$ day). This closure error is likely to decrease if we measured the snowpack energy flux and the energy involved in heating standing water prior to surface runoff.

We also show that in a saturated end-member site, ET will not be as variable as precipitation and precipitation is not the main driver of ET, as it may be in other Rocky Mountain locations. This site is not water-limited and thus useful for constraining ET in the rest of the East River Basin and is behavior that may be applicable across other western US headwater catchments for constraining ET estimations.

Using precipitation, change in soil moisture, and ET values, we can estimate groundwater contributions to ET showing that groundwater may increase ET values by up to $76 \%$. This shows the necessity in constraining these variables at high-elevation basins and additional observations are needed to better estimate ET from groundwater across the rest of the East River Basin.

Both precipitation and ET are highly variable across the basin with an increase in ET of $13-22 \%$ when the missing data is estimated through gap-filling and a difference in precipitation of about 140-660mm depending on the water year and meteorological station used. This variability can change a wet year from a gaining system into a losing system creating complications for estimating water availability and planning downstream water consumption. These results again highlight the need for additional eddy covariance observations and meteorological stations in both the East River and other high-elevation basins.

Comparison of the East River eddy flux estimations with those from the other two eddy flux towers in the Rocky Mountains allow for constraining ET across the rest of the East River basin and other similar mountain headwater regions. ET values in the East River basin should be equal to or less than those at the eddy flux location. ET at higher elevations should be similar to the magnitudes of ET seen at Niwot Ridge given the similarities between Niwot Ridge and the high-elevation locations in the East River basin.

The ability to quantify these fluxes, particularly ET, is useful for estimating water availability downstream from headwaters catchments. Though this study presents a useful dataset for water and energy fluxes in 
complex headwater regions, access to more eddy covariance towers in diverse locations across the basin, would allow for better estimations of ET and other water and energy fluxes across an entire basin leading to better water availability predictions that are useful for downstream water planning.

\section{References}

Aubinet, M., Vesala, T., \& Papale, D. (Eds.). (2012). Eddy Covariance: A Practical Guide to Measurement and Analysis .

Baldocchi, D.D., Hincks, B.B., \& Meyers, T.P. (1988). Measuring Biosphere-Atmosphere Exchanges of Biologically Related Gases with Micrometeorological Methods. Ecology , vol. 69, no. 5. pp. 1331-40. doi:10.2307/1941631

Bearup, L.A., Maxwell, R.M., Clow, D.W., \& McCray, J.E. (2014). Hydrological effects of forest transpiration loss in bark beetle-impacted watersheds. Nature Climate Change, vol. 4 , pp. 481-486. doi:10.1038/NCLIMATE2198

Burba, G., \& Anderson, D. (2006). Introduction to the eddy covariance method: General guidelines and conventional workflow . pp. 1-141.

Burba, G. (2013). Eddy Covariance Method for Scientific, Industrial, Agricultural and Regulatory Applications: A Field Book on Measuring Ecosystem Gas Exchange and Areal Emission Rates. LI-COR Biosciences, Lincoln, USA. pp. 1-331.

Burns, S. P., Blanken, P. D., Turnipseed, A. A., Hu, J., \& Monson, R. K. (2015). The influence of warmseason precipitation on the diel cycle of the surface energy balance and carbon dioxide at a colorado subalpine forest site. Biogeosciences,12(23), pp. 7349-7377.

Carroll, R.W.H \& Williams, K.H. (2019). Discharge data collected within the East River for the Lawrence Berkeley National Laboratory Watershed Function Science Focus Area (water years 2015-2018). Watershed Function SFA. Doi:10.21952/WTR/1495380

Ceperley, N. C., Mande, T., Giesen, N. Van De, Tyler, S., Yacouba, H., \& Parlange, M. B. (2017). Evaporation from cultivated and semi-wild Sudanian Savanna in west Africa. Hydrology and Earth Systems Sciences , vol. 21 , pp. 4149-4167.

Chang, A. T. C., Foster, J. L., Hall, D. K., Rango, A., \& Hartline, B. K. (1982). Snow water equivalent estimation by microwave radiometry. Cold Regions Science and Technology , 5 , pp. 259-267.

Eshonkulov, R., Poyda, A., Ingwersen, J., Wizemann, H., Weber, T. K. D., Kremer, P., .. Streck, T. (2019). Evaluating multi-year, multi-site data on the energy balance closure of eddy-covariance flux measurements at cropland sites in southwestern Germany.Biogeosciences, vol. 16, pp. 521-540.

Finnigan, J. (2004). Advection and modeling. In: Lee, X., Massman, W., Law, B. (Eds.), Handbook of Micrometeorology . Kluwer Academic Publishers, Dordrecht, pp. 209-244.

Flerchinger, G. N., Marks, D., Reba, M.L., Yu, Q., \& Seyfried, M.S. (2010). Surface fluxes and water balance of spatially varying vegetation within a small mountainous headwater catchment. Hydrology and Earth System Sciences, vol. 14, no. 6 , pp. 965-978. doi:10.5194/hess-14-965-2010

Frank, J. M., Massman, W.J., Ewers, B.E., Huckaby, L.S., \& Negron, J.F. (2014). Ecosystem CO2 /H2O fluxes are explained by hydraulically limited gas exchange during tree mortality from spruce bark beetles. Journal of Geophysical Research: Biogeosciences,119 (6), pp. 1195-1215.

Healy, R.W., Winter, T.C., LaBaugh, J.W., \& Franke, O.L. (2007). Water budgets: Foundations for effective water-resources and environmental management. U.S. Geological Survey Circular , vol. 1308, pp. 41-43. doi:10.1016/j.cell.2008.09.034 
Hirschi, M., Michel, D., Lehner, I., \& Seneviratne, S.I. (2017). A site-level comparison of lysimeter and eddy covariance flux measurements of evapotranspiration, pp. 1809-1825. http://doi.org/10.5194/hess-21-18092017

Hubbard, S. S., Williams, K. H., Agarwal, D., Banfield, J., Beller, H., Bouskill, N., ... Varadharajan, C. (2018). The East River, Colorado, Watershed: A mountainous community testbed for improving predictive understanding of multiscale hydrological-biogeochemical dynamics. Vadose Zone Journal , 17 (1), 180061. https://doi.org/10.2136/vzj2018.03.0061

Ikeda, K., Rasmussen, R., Liu, C., Gochis, D., Yates, D., Chen, F., .. Guttman, E. (2010). Simulation of seasonal snowfall over Colorado. Atmospheric Research , 97 (4), pp. 462-477. http://doi.org/10.1016/j.atmosres.2010.04.010

Knight, D., Fahey T., \& Running, S. (1981). Whole-tree potometers estimate pine forest transpiration. Bioscience.

Kollet, S.J. \& Maxwell, R.M. (2008). Capturing the influence of groundwater dynamics on land surface processes using an integrated, distributed watershed model. Water Resources Research 44: W02402. doi:10.1029/2007WR006004

Litvak, Marcy. (2007-). AmeriFlux US-Vcp Valles Caldera Ponderosa Pine, Dataset. https://doi.org/10.17190/AMF/1246122

Maes, W.H., Gentine, P., Verhoest, N.E.C., \& Miralles, D.G. (2019). Potential evaporation at eddycovariance sites across the globe.Hydrology and Earth System Sciences, vol. 23, pp. 1-33.

Mamadou, O., Cohard, J.M., Galle, S., Awanou, C.N., Diedhiou, A., Kounouhewa, B., \& Peugeot, C. (2014). Energy fluxes and surface characteristics over a cultivated area in Benin: daily and seasonal dynamics. Hydrology and Earth System Sciences , 18 (3), pp. 893-914. http://doi.org/10.5194/hess-18-893-2014

Massman, W. J. (2001). Reply to comment by Rannik on "A simple method for estimating frequency response corrections for eddy covariance systems." Agricultural and Forest Meteorology, 107 , pp. 247-251.

Mastrotheodoros, T., Pappas, C., Molnar, P., Burlando, P., Manoli, G., Parajka, J., .. Fatichi, S. (2020). More green and less blue water in the Alps during warmer summers. Nature Climate Change, 10 , pp.155161. https://doi.org/10.1038/s41558-019-0676-5

Maxwell, R.M. \& Kollet, S.J. (2008). Interdependence of groundwater dynamics and land-energy feedbacks under climate change. Nature Geoscience, 1 (10), pp. 665-669. doi:10.1038/ngeo315

Maxwell, R.M., Condon, L.E., Danesh-Yazdi, M., \& Bearup, L.A. (2019). Exploring source water mixing and transient residence time distributions of outflow and evapotranspiration with an integrated hydrologic model and Lagrangian particle tracking approach. Ecohydrology , 12 (1):e2042. doi:10.1002/eco.2042

Maxwell, R.M. \& Condon, L.E. (2016). Connections between groundwater flow and transpiration partitioning. Science , 353 :6297, pp. 377-380. doi:10.1126/science.aaf7891

Milly, P., \& Dunne, K. (2020). Colorado River flow dwindles as warming-driven loss of reflective snow energizes evaporation. Science, 367 (6483), pp. 1252-1255. doi: https://doi.org/10.1126/science.aay9187

Monson, R.K., Turnipseed, A.A., Sparks, J.P., Harley, P.C., Scott-Denton, L.E., Sparks, K., \& Huxman, T.E. (2002). Carbon sequestration in a high-elevation, subalpine forest. Global Change Biology , 8 (5), pp. 459-478.

Nagler, Pamela L., Scott, R.L., Westenburg, C., Cleverly, J.R., Glenn, E.P., \& Huete, A.R. (2005). Evapotranspiration on western U.S. rivers estimated using the enhanced vegetation index from MODIS and data from eddy covariance and bowen ratio flux towers. Remote Sensing of Environment, vol. 97, no. 3, pp. 337-51. doi:10.1016/j.rse.2005.05.011 
Natural Resources Conservation Service. (1984-). Schofield Pass Site Number 737. United States Department of agriculture, National Water and Climate Center.

Reclamation, B. of. (2012). Managing Water in the West: Colorado River Basin Water Supply and Demand Study.

Sexstone, G.A., Clow, D.W., Fassnacht, S.R., Liston, G.E., Hiemstra, C.A., Knowles, J.F., \& Penn, C.A. (2018). Snow sublimation in mountain environments and its sensitivity to forest disturbance and climate warming. Water Resources Research , 54 (2), pp. 1191-1211. https://doi.org/10.1002/2017WR021172

Scott, R.L., Edwards, E.A., Shuttleworth, W.J., Huxman, T.E., Watts, C., \& Goodrich, D.C. (2004). Interannual and seasonal variation in fluxes of water and carbon dioxide from a riparian woodland ecosystem.Agricultural and Forest Meteorology , vol. 122 , no. 1-2, pp. 65-84. doi:10.1016/j.agrformet.2003.09.001

Scott, R.L., Cable, W.L., Huxman, T.E., Nagler, P.L., Hernandez, M., \& Goodrich, D.C. (2008). Multiyear riparian evapotranspiration and groundwater use for a semiarid watershed. Journal of Arid Environments, vol. 72, no. 7, pp. 1232-1246. doi:10.1016/j.jaridenv.2008.01.001

Tokunaga, T.K., Wan, J., Williams, K.H., Brown, W., Henderson, A., Kim, Y., .. Hubbard, S.S. (2019). Depth- and time-resolved distributions of snowmelt-driven hillslope subsurface flow and transport and their contributions to surface waters. Water Resources Research , 55 (11), 9474-9499. https://doi.org/10.1029/2019WR025093

Trenberth, K.E., Smith, L., Qian, T., Dai, A., \& Fasullo, J. (2007). Estimates of the global water budget and its annual cycle using observational and model data. Journal of Hydrometeorology,8 (4), pp. 758-769.

Webb, E.K., Pearman, G.I., \& Leuning, R. (1980). Correction of flux measurements for density effects due to heat and water vapor transfer.Quarterly Journal of the Royal Meteorological Society ,106 , pp. 85-106.

Wilczak, J.M., Oncley, S.P., \& Stage, S.A. (2001). Sonic anemometer tilt correction algorithms. BoundaryLayer Meteorology ,99 (1), pp. 127-150. https://doi.org/10.1023/A:1018966204465

Wilson, K., Goldstein, A., Falge, E., Aubinet, M., Baldocchi, D., Berbigier, P., ... Valentini, R. (2002). Energy balance closure at FLUXNET sites. Agricultural and Forest Meteorology, 113 , pp. 223-243.

Yang, L., Jin, S., Danielson, P., Homer, C.G., Gass, L., Bender, S.M., .. Xian, G. (2018). A new generation of the United States National Land Cover Database - Requirements, research priorities, design, and implementation strategies. ISPRS Journal of Photogrammetry and Remote Sensing, v. 146 , pp. 108123. https://doi.org/10.1016/j.isprsjprs.2018.09.006

\section{Data Availability Statement}

All data from this study will be made openly and publicly available through the Watershed Function ESSDIVE community repository:

https://data.essdive.lbl.gov/data/query=Watershed\%20Function\%20SFA upon publication. In additional to being assigned a DOI, all metadata will be included to ensure that these data are FAIR: Findable, Accessible, Interoperable and Reproducible.

\section{Tables}

Table 1: Eddy covariance/energy balance tower sensor suite

\begin{tabular}{llll}
\hline Meteorological Variable & Sensor & Make/Model & Sampling Frequency \\
\hline Wind Speed & 3-dimensional sonic & Campbell Scientific & $10 \mathrm{~Hz}$ \\
& anemometer & IRGASON & \\
Air Temperature & sonic anemometer & Campbell Scientific & $10 \mathrm{~Hz}$
\end{tabular}




\begin{tabular}{llll}
\hline Meteorological Variable & Sensor & Make/Model & Sampling Frequency \\
\hline Barometric Pressure & sonic anemometer & $\begin{array}{l}\text { Campbell Scientific } \\
\text { IRGASON }\end{array}$ & $10 \mathrm{~Hz}$ \\
$\begin{array}{l}\text { Water Vapor } \\
\text { Concentration }\end{array}$ & infra-red gas analyzer & $\begin{array}{l}\text { Campbell Scientific } \\
\text { IRGASON }\end{array}$ & $10 \mathrm{~Hz}$ \\
$\begin{array}{l}\text { CO }{ }_{2} \text { Gas } \\
\text { Concentration }\end{array}$ & infra-red gas analyzer & $\begin{array}{l}\text { Campbell Scientific } \\
\text { IRGASON }\end{array}$ & $10 \mathrm{~Hz}$ \\
$\begin{array}{l}\text { Incoming/Outgoing } \\
\text { Shortwave/Longwave }\end{array}$ & ingoing/outgoing & Kipp and Zonen CNR-4 & 15 minutes \\
Radiation & incoming/outgoing & & \\
& pyrgeometer & Huskeflux & \\
Soil Heat Flux & heat flux plate & self-calibrating soil & 15 minutes \\
& heat flux plate & \\
Soil Temperature & Soil thermistor & Steven's Hydra-Probe & 15 minutes \\
Soil Moisture & Soil dielectric probe & Steven's Hydra-Probe & 15 minutes \\
Soil Electrical & soil electrical & 15 minutes \\
Conductivity & conductivity probe & Apogee SI-111 & 15 minutes \\
Surface Infra-red Skin & infra-red radiometer & Infra-red radiometer & \\
Temperature & Campbell Scientific & \\
& data logging/control & CR3000 & \\
& system & & \\
\hline
\end{tabular}

Table 2: EasyFlux-DL flux processing options

\begin{tabular}{ll}
\hline Sampling Frequency & $10 \mathrm{~Hz}$ \\
\hline Sensor Orientation & 315 degrees (from North) \\
Measurement Height & 5.9 meters \\
Canopy Height & 2 meters \\
Displacement Height & Diagnosed online \\
Roughness Length & Diagnosed online \\
Site Elevation & 2862 meters ASL \\
Wind Coordinate Rotation & Planar-fit method (Wilczak, Oncley, \& Stage, 2001) \\
Spectral Correction (low pass filter correction) & Massman (2001) \\
Density Corrections & WPL method (Webb, Pearman, \& Leuning, 1990) \\
\hline
\end{tabular}

Table 3: Monthly averages of latent heat, Rn-G, air temperature, dewpoint depression, and total summer ET for June through August 2017, 2018, and 2019 and water year totals of precipitation and ET for 2017, 2018, and 2019.

${ }^{+}$Annual 2017 ET is measured from April 2017 when the tower was installed through the end of the water year (September 30, 2017).

\begin{tabular}{llll}
\hline & Summer 2017 & Summer 2018 & Summer 2019 \\
\hline Latent Heat $\left(\mathrm{W} / \mathrm{m}^{2}\right)$ & 105.23 & 103.92 & 97.40 \\
Summer ET $(\mathrm{mm})$ & 227.80 & 251.75 & 208.91 \\
Annual ET $(\mathrm{mm})$ & $391.81^{+}$ & 448.64 & 410.75 \\
Rn-G $\left(\mathrm{W} / \mathrm{m}^{2}\right)$ & 157.26 & 154.75 & 168.55
\end{tabular}




\begin{tabular}{llll}
\hline & Summer 2017 & Summer 2018 & Summer 2019 \\
\hline Air Temperature (K) & 286.59 & 286.41 & 285.56 \\
Dew Point Depression & 11.42 & 12.13 & 12.04 \\
Precipitation (mm) from & 1037.5 & 790.13 & 1115.61 \\
Billy Barr Station & & & \\
\hline
\end{tabular}

Table 4: Summer (May through September, Mountain Time) East River water balance components for groundwater use in $\mathrm{mm}$.

\begin{tabular}{llll}
\hline & Summer 2017 & Summer 2018 & Summer 2019 \\
\hline ET & 301.30 & 327.26 & 265.92 \\
$\mathrm{P}$ & 52.95 & 304.10 & $46.00 ? ¿$ ? \\
$\mathrm{S}$ & 18.87 & 20.07 & 19.24 \\
$\mathrm{ET}_{\mathrm{gw}}$ & 229.48 & 3.09 & 200.68 \\
\hline
\end{tabular}

Table 5: Comparison of East River (ER), Valles Caldera (VC), and Niwot Ridge (NR) ET both over the summer (June-August, $\mathrm{mm}$ ) as well as annual ET (mm/year), precipitation cumulative for the water year $(\mathrm{mm})$, and average summer temperature (K). ${ }^{+}$Annual 2017 ET is measured from April 2017 when the tower was installed through the end of the water year (September 30, 2017).

\begin{tabular}{llll}
\hline & 2017 & 2018 & 2019 \\
\hline ER Summer Evapotranspiration (mm) & 227.80 & 251.75 & 208.91 \\
VC Summer Evapotranspiration (mm) & 398.47 & 381.44 & 453.63 \\
NR Summer Evapotranspiration (mm) & 230.53 & 218.31 & 151.63 \\
ER Annual Evapotranspiration (mm/year) & $391.81^{+}$ & 448.64 & 410.75 \\
VC Annual Evapotranspiration (mm/year) & 731.35 & 849.79 & 855.64 \\
NR Annual Evapotranspiration (mm/year) & 320.02 & 464.10 & 499.64 \\
ER Temperature (K) & 286.59 & 286.41 & 285.56 \\
VC Temperature (K) & 289.98 & 290.86 & 290.29 \\
NR Temperature (K) & 285.42 & 286.39 & 284.25 \\
ER Precipitation (mm, cumulative) & 1037.5 & 790.13 & 1115.61 \\
VC Precipitation (mm, cumulative) & 539.56 & 299.51 & 545.69 \\
NR Precipitation (mm, cumulative) & 979.52 & 745.57 & 848.10 \\
\hline
\end{tabular}

Table 6: Precipitation values at the Billy Barr and Schofield sites, ET values and gap-filled ET values, and runoff values for water years 2017, 2018, and $2019 \mathrm{in} \mathrm{mm.}{ }^{+}$Annual 2017 ET is measured from April 2017 when the tower was installed through the end of the water year (September 30, 2017).

\begin{tabular}{llll}
\hline & 2017 & 2018 & 2019 \\
\hline Billy Barr Precip. & 761.83 & 654.04 & 816.12 \\
Schofield Precip. & 1424.94 & 795.02 & 1371.60 \\
ET & $391.81^{+}$ & 448.64 & 410.75 \\
Gap-filled ET & 457.94 & 547.12 & 465.54 \\
Q & 859.13 & 405.38 & 1029.20 \\
\hline
\end{tabular}


Table 7: Residual values calculated from the water balance using Billy Barr and Schofield precipitation as well as ET with gaps from the flux tower and gap-filled ET in $\mathrm{mm}$.

\begin{tabular}{llll}
\hline & $\mathbf{2 0 1 7}$ & $\mathbf{2 0 1 8}$ & $\mathbf{2 0 1 9}$ \\
\hline Billy Barr & -507.98 & -220.05 & -643.08 \\
Billy Barr and ET Gap-filled & -574.11 & -318.52 & -697.87 \\
Schofield & 155.13 & -79.10 & -87.60 \\
Schofield and ET Gap-filled & 89.00 & -177.55 & -142.39 \\
\hline
\end{tabular}

\section{Figure Legends}

Figure 1: a: Location of the East River basin in reference to the United States and Colorado, b: East River watershed with location of eddy covariance tower, c: The East River eddy covariance tower in June, d: The East River eddy covariance tower in September.

Figure 2: Wind direction captured by the eddy covariance tower in five degree increments.

Figure 3: Daily soil moisture from June 2, 2017 to September 27, 2019 for four sensors with two sensors located $5 \mathrm{~cm}$ from the surface and two sensors located $25 \mathrm{~cm}$ from the surface.

Figure 4: Monthly percentages of energy balance closure error for June 2017 to August 2019. The dotted lines represent negative and positive 30 percent closures.

Figure 5: Diurnal cycle of net radiation, latent heat, sensible heat, ground heat fluxes, and closure error along with the range of solar noon from June 1 to August 31 for summers 2017, 2018, and 2019 Mountain Time.

Figure 6: Average monthly values for May through September 2017, 2018, and 2019. a: Average monthly available energy values (Rn-G) data for May of 2017 missing as the soil heat flux sensor was not yet installed. b: Average monthly ET values. c: Average monthly soil moisture values for two sensors $25 \mathrm{~cm}$ from the surface with data for May of 2017 missing as the sensor was not yet installed. d: Average monthly soil moisture values for two sensors $5 \mathrm{~cm}$ from the surface with data for May of 2017 missing as the sensor was not yet installed.

Figure 7: Daily ET estimates from the East River eddy covariance tower in comparison with the Niwot Ridge eddy covariance tower for May 2017 through September 2019 with grey boxes marking times of good energy balance closure (May-September, Mountain Time).
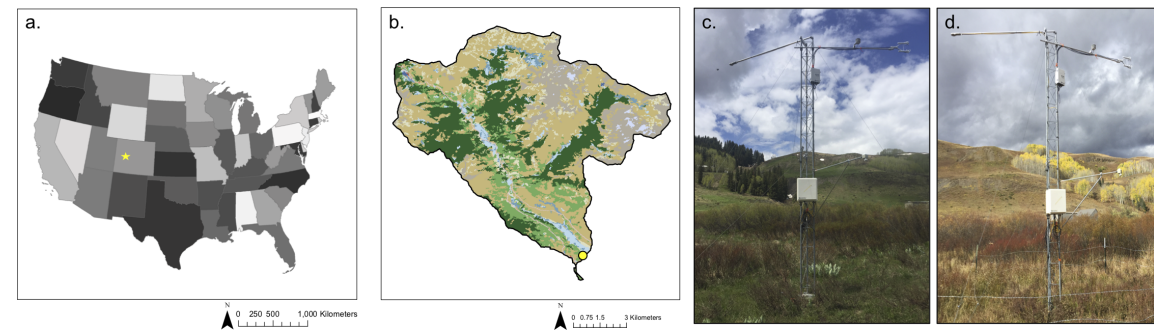



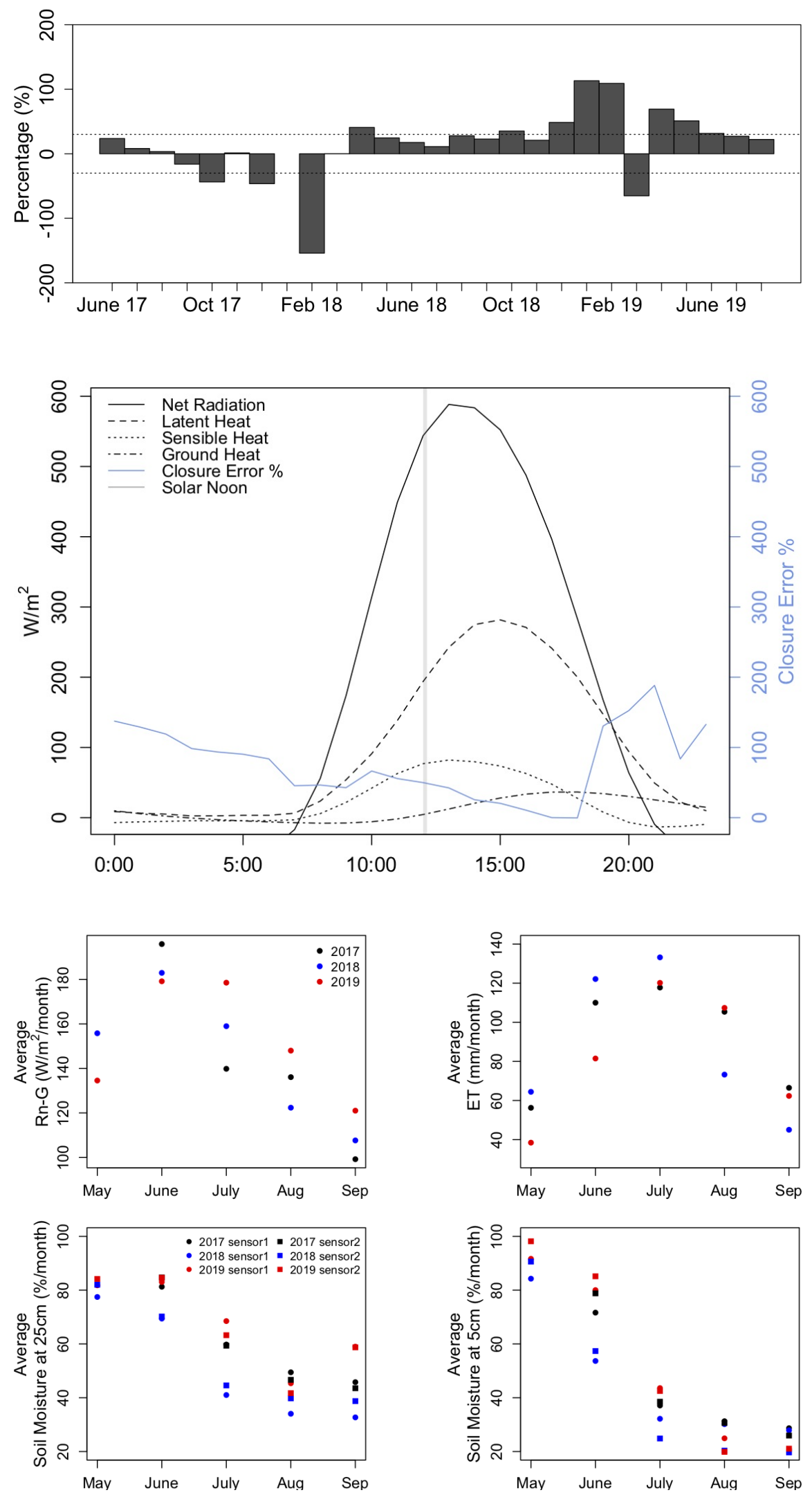


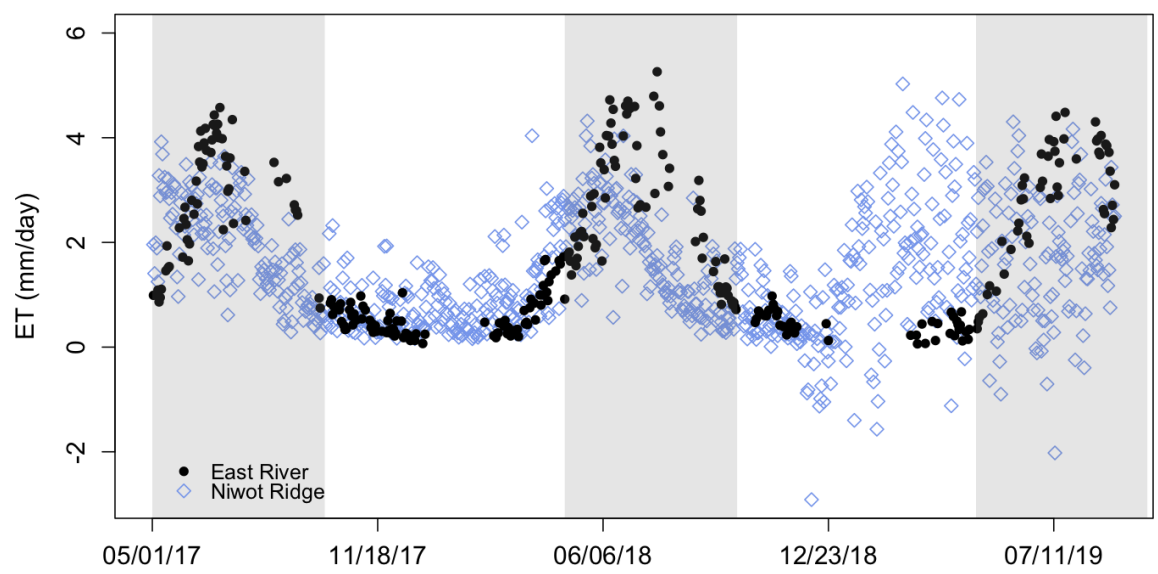

